Christian Studies" 9 (2001) 421-452. Można mieć nadzieję, że wyżej wymienione publikacje, a przede wszystkim przekład Teologii judeochrześcijańskiej J. Daniélou przyczynią się do ożywienia zainteresowań polskich patrologów najstarszą teologią chrześcijańską.

ks. Stanisław Longosz - Lublin

\title{
Judith LIEU, Image and reality: the Jews in the world of the Christians in the second Century, Edinburgh 1996, Clark, ss. XIV + 349.
}

Choć praca Autorki pochodzi z 1996 r., to jednak sądzę, iż ze względu na jej ważność warto ją przybliżýc również badaczom polskim, zwłaszcza zajmującym się literaturą patrystyczną bądź tematyką relacji pomiędzy chrześcijaństwem a judaizmem antycznym.

We wstępie Autorka kreśli swego rodzaju status quaestionis badań nad naszą tematyką. Otóż, od dawna już badacze starożytności chrześcijańskiej podkreślali, że chrześcijaństwo, chcąc zbudować własną tożsamość, było niejako zmuszone zbudować na swój własny użytek tożsamość „innego”, tzn. judaizmu i świata pogańskiego. W odpowiedzi więc na tak skonstruowany „wykrzywiony" obraz judaizmu, bo zasadniczo ta właśnie tematyka nas tutaj interesuje, wielu uczonych podjęło trud ponownego przebadania źródeł go dotyczących (np. E.P. Sanders, Judaism, Practise and Belief, London 1992); inni z kolei zajęli się aspektami polemiki chrześcijańsko-żydowskiej w pierwszych wiekach. Owocem tych badań było wyraźne podkreślenie, z jednej strony roli, jaką odegrały konkretne potrzeby teologiczne rodzącego się Kościoła w polemice z judaizmem, $\mathrm{z}$ drugiej zaś pokazanie, jak myląca może być próba prezentacji tzw. late Judaism jako monolitu. Nie bez znaczenia było również zastąpienie określeń typu „chrześcijański anty-judaizm” analizami konkretnych autorów, różnorodnych kontekstów historycznych czy teologicznych wraz z uwzględnieniem różnych form literackich. Nowsze studia nad anty-judaizmem w źródłach wczesnochrześcijańskich (por. bibliografia przedstawiona przez Autorkę) doszły do wniosku, że nie jest on opisem judaizmu, ale raczej samych chrześcijan i ich obaw wobec religii żydowskiej. W taki właśnie kontekst badań wpisuje się praca Autorki, która, jak sama podkreśla, nie chce studiować anty-judaizmu jako takiego, ale sposoby, w jaki Żydzi i judaizm są opisani przez poszczególnych autorów chrześcijańskich w różnych kontekstach historycznych. Nie chce również koncentrować się na argumentach teologicznych w dyskusji chrześcijańsko-żydowskiej tamtej epoki, gdyż, jej zdaniem, są one marginalne w przypadku studium chrześcijańskiej prezentacji Żydów i judaizmu. Ta prezentacja zależy bowiem zasadniczo, jej zdaniem, od dwóch faktorów: literackich form tekstu oraz kontekstu społecznego i funkcji, jaką w nim miał spełniać sam tekst. 
Autorka świadoma jest również faktu, że konkretna forma literacka nie zawsze odzwierciedla bezpośrednio sytuację rzeczywistą, ale często odpowiada na konkretne problemy, podobnie jak konkretne sytuacje mogą wpłynąć na wybór określonej formy literackiej. Stąd tytuł pracy „obraz i rzeczywistość”, gdzie Autorka rozumie przez „obraz” prezentację Żydów i judaizmu w źródłach chrześcijańskich, a przez „rzeczywistość” realną sytuację Żydów w relacji do siebie samych lub do chrześcijan w kontekście, z którego dany tekst pochodzi, zrekonstruowanym w oparciu o inne źródła. Podejmuje się więc niełatwego zadania utrzymania razem elementów zmiennych i stałych. Ogranicza jednak czasowo zakres tekstów chrześcijańskich do badania jedynie do II wieku, a geograficznie do pism powstałych w Azji Mniejszej. Słusznie opowiada się za realnością relacji pomiędzy Żydami i chrześcijanami w II wieku, odrzucając wnioski wcześniejszych badań, które widziały w Żydach wytwór podszytej lękiem wyobraźni chrześcijańskiej. A. Harnack określił to mianem „Żyda, którego chrześcijanie się lękali”. Chrześcijanie Azji Mniejszej znali elementy praktyk liturgicznych i egzegezy żydowskiej, i nie da się wyjaśnić tej znajomości jedynie wspólnym dziedzictwem biblijnym Starego Testamentu.

W poszczególnych rozdziałach książki, a jest ich razem oprócz wstępu i zakończenia sześć, Autorka zajmuje się Listami Ignacego Antiocheńskiego, Martyrium Polycarpi, Dialogiem z Żydem Tryfonem Justyna, Apologia Arystydesa z Aten, Homiliq Paschalna Melitona z Sardes, oraz tradycjami starszych wspominanymi przez Polikarpa i Papiasza. Różnorodność form literackich i kontekstów społecznych tych tekstów pokazuje zasadniczą słuszność metodologicznych założeń Autorki, by wstępnie zawiesić osąd historyczny i analizować, w jaki sposób prezentacja Żydów i judaizmu wpisuje się w strukturę każdego $\mathrm{z}$ tych tekstów. Autorka stara się więc odpowiedzieć na pytania: jaka jest retoryczna funkcja Żydów i judaizmu w tekstach II wieku? W jakiej relacji pozostaje ona do innych, np. do funkcji historycznej, teologicznej czy społecznej? Jaki wpływ posiadały te dzieła na późniejsze, znacznie bardziej stereotypowe przedstawienie Żydów i judaizmu w literaturze chrześcijańskiej III i IV wieku? Według Autorki owa retoryczna funkcja prezentacji Żydów i judaizmu w literaturze chrześcijańskiej II wieku dotyczyła kilku obszarów: „,walki o Stary Testament" (Ignacy, Justyn, Meliton), przedstawiania Żyda jako archetypu nieprzyjaciela Chrystusa i chrześcijan (Arystydes, Ewangelia Piotra, Meliton, Justyn, Martyrium Polycarpi), prześladowania i męczeństwa, projekcji wewnętrznego konfliktu (walka z Marcjonem o Stary Testament kosztem Żydów, Martyrium Polycarpi o czci męczenników, kontrowersja z kwartodecymanami), w podkreśleniu odrębności samego chrześcijaństwa, wykorzystywaniu argumentów świata pogańskiego (np. Ignacy o szabacie czy obrzezaniu, Justyn o Powstaniu Bar Kochby, Meliton), zabieganie o nowych wyznawców (Justyn), kształtowanie obrazu Żyda i judaizmu, który przetrwał czy wręcz ulegl wzmocnieniu w następnych wiekach (krytyka Tory, chrześcijańska interpreta- 
cja proroctw Starego Testamentu, zniszczenie Świątyni jako kara za odrzucenie Jezusa).

Obraz Żydów i judaizmu w tekstach chrześcijańskich II wieku zmienia się w zależności od autora, kontekstu historycznego i formy literackiej jego pisma. Autorka konkluduje, że choć, co prawda, bardzo trudno byłoby zaproponować jako podstawową charakterystykę chrześcijaństwa II wieku walkę z judaizmem, nie można jednak zaprzeczyć, że dziecko (chrześcijaństwo) budowało swoją tożsamość na konflikcie ze swoją matką (judaizmem). Autorzy chrześcijańscy budowali, jej zdaniem, obraz Żyda skrojony dla własnych potrzeb społecznych, teologicznych czy politycznych i poprzez taką prezentację dawni ,sąsiedzi stali się Żydami”.

Książka ta, zresztą bardzo wartościowa od strony metodycznej i dobrej analizy źródeł, budzi jednak we mnie trzy wątpliwości. Po pierwsze, Autorka zakłada i nigdzie nie uzasadnia tego założenia, że prezentacja Żydów i judaizmu w tekstach chrześcijańskich II wieku powstałych w Azji Mniejszej ma charakter retoryczny i służy raczej określeniu tożsamości samego chrześcijaństwa niż jest opisem rzeczywistej sytuacji. Jeśli byśmy natomiast założyli, że rzeczywistość (reality) jest nam dostępna tylko poprzez obraz (image), jak zdaje się czynić Autorka, to otwarte ciągle pozostaje pytanie na ile obraz odzwierciedla zewnętrzną rzeczywistość historyczną, nie zaś subiektywny odbiór autora. Wiemy bowiem, że historia „obiektywna” nie istnieje, a przeszłość zostaje przefiltrowana przez świadomość piszącego. Wtedy trzeba by w ogóle zrezygnować z określenia „historia" i pisać o wewnętrznych, subiektywnych przeżyciach autora. Możemy je oczywiście konfrontować z innymi opisami, by tę subiektywność w opisie konkretnego autora określić, ale inne opisy też są subiektywne. Dotykamy tutaj pytania natury filozoficznej o moźliwość poznania przeszlości w ogóle i nie miejsce tutaj na udzielanie na nie odpowiedzi. Autorka stara się określić, i jest to druga moja wątpliwość, relację pomiędzy image (Żydzi w pismach chrześcijańskich) a reality (rzeczywista sytuacja Żydów (w Azji Mniejszej) w oparciu o inne źródła żydowskie, jak np. dzieła Józefa Flawiusza czy Filona Aleksandryjskiego. Oprócz tego, że same te teksty są również subiektywnym zapisem autorów, to jeszcze powstały o wiele wcześniej, niż teksty chrześcijańskie z II wieku i ich opis raczej trudno będzie odnieść do sytuacji judaizmu w Azji Mniejszej II wieku. Porównanie jest więc pomiędzy dwoma obrazami, a nie obrazem i rzeczywistością. I po trzecie, nie wiem dlaczego Autorka określiła argumentację teologiczną jako marginalną w prezentacji Żydów i judaizmu przez pisarzy chrześcijańskich II wieku, koncentrując się na wątkach literackich i społecznych. W niektórych przecież przypadkach, jak np. u Justyna, to właśnie argumenty teologiczne wpłynęły na wybór konkretnej formy literackiej i spoleczny odbiór tekstu.

Niezależnie od tych zastrzeżeń, omawiane studium jest bardzo wartościowe i dobrze wydane, choć trochę nużące jest ciągłe szukanie przypisów na końcu 
poszczególnych rozdziałów. Książka zawiera wyczerpującą bibliografię, w większości niestety anglojęzyczną, oraz dokładne indeksy przedmiotowe i cytowanych źródeł. Przez najbliższe dziesięciolecia praca ta stanowić będzie bez wątpienia lekturę obowiązkową dla tych wszystkich, którzy będą się zajmować relacjami pomiędzy chrześcijaństwem a judaizmem w II wieku.

ks. Leszek Misiarczyk - Plock

\section{David ROKÉAH, Justin Martyr and the Jews, Leiden - Boston - Köln 2002, Brill, ss. 157.}

Prezentowane poniżej studium, choć w wersji anglojęzycznej ukazuje się dopiero teraz, jest jednak tłumaczeniem uzupełnionej wersji dzieła autora z języka hebrajskiego, wydanej już w 1998 roku przez wydawnictwo Uniwersytetu Hebrajskiego w Jerozolimie. Praca jest niewielka objętościowo (134 strony tekstu) i została pomyślana, jak to zresztą zaznacza w przedmowie sam Autor, jako wprowadzenie do thumaczenia na język hebrajski Dialogu Justyna, które właśnie przygotowuje. Znajdują się w niej więc również refleksje przedstawione już wcześniej w innych artykułach tego samego Autora, a dotyczące chrześcijańskich korzeni antysemityzmu, tematu tyleż modnego, co mało precyzyjnego. Autor więc zaraz w przedmowie definiuje wybranie Izraela, obecne zarówno w Biblii Hebrajskiej i literaturze rabinicznej, jak też w Nowym Testamencie, zwłaszcza w Ewangeliach synoptycznych, jako oparte na trzech zasadniczych faktorach: wybór Abrahama i jego potomków, powierzenie Izraelowi Tory, i niższość pogan. Zdaniem autora, św. Paweł starał się odrzucić te prawdy, przenosząc ideę boskiego wybrania z Żydów na chrześcijan. Justyn rozwinąłby tę argumentacją Pawłową, koncentrując swój Dialog właśnie na owych trzech kluczowych tematach: Abraham i jego potomkowie, wartość Tory i status pogan. W ten sposób Justyn wypełniłby plan św. Pawła, gdyż obydwaj głosili, że poganie są spadkobiercami obietnic udzielonych przez Boga Abrahamowi, podczas gdy Żydzi zostaliby odrzuceni i wydziedziczeni, ponieważ nie uwierzyli w Jezusa jako Mesjasza. W konsekwencji więc, wedhug Autora, współczesny dialog chrześcijańsko-żydowski nie będzie niczym więcej, niż swego rodzaju ,grupową terapią” dopóty, dopóki chrześcijanie nie odrzucą Listów Pawłowych jako źródła swej inspiracji. Komuś może wydawać się dziwne, że tyle miejsca poświęcam przedmowie autora, ale sądzę, iż jest ona kluczowa do zrozumienia reszty książki.

Praca składa się ze wstępu, zresztą bardzo zdawkowego (3,5 strony), i dziesięciu tematycznych rozdziałów. Rozdziały I-V to zasadniczo powtórka znanych już od dawna badaczom Dialogu Justyna i szeroko dyskutowanych kwestii. A więc najpierw: chronologia życia Justyna i datacja Dialogu (rozdz. I), 